\title{
AN ASSESSMENT OF RISK AND RISK MANAGEMENT INFORMATION DISCLOSURE OF COMPANIES LISTED IN NASDAQ OMX BALTIC AND EURONEXT BRUSSELS
}

\author{
Kolmatsui, D., Legenzova, R., Seilius, M.
}

The main goal of this paper is to discuss theoretically and to evaluate empirically the differences of risk and risk management information disclosure (RRMID) among companies listed in Nasdaq OMX Baltic and Euronext Brussels and to determine factors influencing such differences. The authors use analysis and systemization of scientific literature, induction, content analysis and coding procedure for risk and risk management information disclosure assessment, as well as correlation and regression analyses. The results suggest that companies listed in Euronext Brussels disclose more risk and risk management (RRM) information; RRM related disclosures are more qualitative, focused on past or present events and have a neutral meaning in both markets. Companies also disclose more information about risks themselves than about risk management. Finally, only companies' size and presence of audit committee are significant factors influencing RRMID.

Keywords: Risk management; information disclosure; Nasdaq OMX Baltic; Euronext Brussels JEL classification: M41, G30

\section{Introduction}

Corporate risk is inevitable and it is necessary to analyze and observe it on a continual basis. This process helps control and supervise companies' activities. Control and supervision are essential, because a certain probability of losing something exists all the time. Consequently, corporate risk is related to losses, certain expenditures or probability of failure (Mackevicius, 2006).

The incrementing intricacy in business strategies, processes, operations and regulations has boosted a certain tendency that highlights the need for a greater amount of information provided by companies to foster transparency, improve the quality of disclosed information and reduce information asymmetries between companies and investors. In the scope of corporate communication, RRMID is an issue which stands out significantly and can be improved (Domínguez and Gámez, 2014).

The goal of this research is to assess the differences in risk and risk management information disclosure among the companies listed in emerging (Nasdaq OMX Baltic) and developed (Brussels Euronext) markets and to determine factors influencing them. Three main hypotheses are developed. All of them include sub-hypotheses for a better and more detailed evaluation. Table 1 summarizes all hypotheses and sub-hypotheses which are tested in the research. 


\begin{tabular}{|c|c|}
\hline$H_{1}:$ & $\begin{array}{l}\text { RRMID of companies listed in Nasdaq OMX Baltic and Euronext Brussels is different } \\
\text { in specific disclosure characteristics }\end{array}$ \\
\hline$H_{1(1)}:$ & The extent of financial RRMID is higher than non-financial RRMID; \\
\hline$H_{1(2)}:$ & The extent of qualitative RRMID is higher than quantitative RRMID; \\
\hline$H_{1(3)^{\circ}}:$ & The extent of past and present RRMIDs is higher than forward looking RRMID; \\
\hline $\mathrm{H}_{1(4)^{\prime}}$ : & The extent of good RRMID is higher than bad or neutral RRMIDs'; \\
\hline$H_{1(5)}:$ & The extent of risks-related disclosures is higher than risk management disclosures; \\
\hline$H_{1(6)}:$ & The extent of mandatory RRMID is higher than voluntary RRMID. \\
\hline $\mathrm{H}_{2}:$ & $\begin{array}{l}\text { RRMID of companies listed in Nasdaq OMX Baltic and Euronext Brussels is influenced } \\
\text { by particular factors }\end{array}$ \\
\hline & Company's characteristics: \\
\hline $\mathrm{H}_{2 \mathrm{a}(1)}:$ & There is a positive relationship between RRMID and companies' size; \\
\hline $\mathrm{H}_{2 \mathrm{a}(2)}:$ & Companies operating in the same industry disclose similar extent of RRM information; \\
\hline $\mathrm{H}_{2 \mathrm{a}(3)^{2}}$ & There is a positive relationship between RRMID and companies' performance; \\
\hline $\mathrm{H}_{2 \mathrm{a}(4)}:$ & There is a positive relationship between RRMID and companies' liquidity; \\
\hline $\mathrm{H}_{2 \mathrm{a}(5)}:$ & There is a positive relationship between RRMID and companies' beta coefficient; \\
\hline$H_{2 a(6)}:$ & There is a positive relationship between RRMID and companies' external auditor; \\
\hline $\mathbf{H}_{2 \mathrm{a}(7)}:$ & $\begin{array}{l}\text { There is a positive relationship between RRMID and companies' listing duration on the } \\
\text { stock exchange. }\end{array}$ \\
\hline & Corporate governance characteristics: \\
\hline$H_{2 b(1)}:$ & There is a negative relationship between RRMID and companies' ownership concentration; \\
\hline$H_{2 b(2)}:$ & There is a positive relationship between RRMID and companies' board size; \\
\hline$H_{2 b(3)}:$ & There is a positive relationship between RRMID and companies' number of non-executives; \\
\hline $\mathrm{H}_{2 \mathrm{~b}(4)}$ : & There is a negative relationship between RRMID and companies' duality of CEO \\
\hline$H_{2 b(5)}:$ & There is a positive relationship between RRMID and companies' presence of internal audit; \\
\hline$H_{2 b(6)}:$ & $\begin{array}{l}\text { There is a positive relationship between RRMID and companies' presence of audit } \\
\text { committee. }\end{array}$ \\
\hline $\mathrm{H}_{3}:$ & $\begin{array}{l}\text { The level of RRMID is different among companies listed in emerging (Nasdaq OMX } \\
\text { Baltic) and developed (Euronext Brussels) markets }\end{array}$ \\
\hline
\end{tabular}

Source: authors

\section{Literature Review}

In the current economic environment, risk management is considered to be a vital part of a company's internal control and also as a fundamental element of the business process management. However, due to the lack of regulations, norms and uniform measures, there is an absence of transparency in RRMID (Lajili and Zeghal, 2005).

The Institute of Chartered Accountants in England and Wales (ICAEW, 2011) argues that improving the investors ' understanding of business risks and simultaneously improving the awareness of corporate reporting to all users should lead to a better stewardship of the company and a more efficient allocation of resources. Linsley and Shrives (2001) confirm this idea saying that RRMID information might be beneficial 
for investors in assessing the risk profile of the company, evaluating the market value of the company or even forecasting its stock price. Moreover, it might be useful for measurement of the quantity and extent of future cash flows (Linsley and Shrives, 2001), or reduction of the cost of capital (Linsley and Shrives, 2001; ICAEW, 2011). RRMID provides information on the direction of future business (Cabedo and Tirado, 2004) and enables companies to convey a message to the investors about the risks that the company confronts and about the methods that are used to manage those risks (Abraham et al., 2007).

It is solidly agreed that RRMID is requisite. However, a discussion arises clarifying whether it should be mandatory or voluntary (Domínguez and Gámez, 2014). In general, mandatory risk-related disclosure represents only a small part of total RRM information. The International Accounting Standards Board (IASB) has issued a set of disclosure requirements for financial risks (IFRS 7). Therefore, companies provide information about other risks on a voluntary basis. There are some theories which support voluntary disclosure. According to Barako et al. (2006), agency theory reveals that voluntary disclosure mitigates the agency problem, because the information disclosed by the managers reduces agency costs. Nevertheless, RRMID can be harmful for the company as well. The RRMID information is available publicly for everyone; therefore, it is obvious that not only the investors but also competitors might use it.

Looking back at the asymmetry theory, it is assumed that managers possess a higher volume of credible risk information as compared to outsiders (Dobler, 2008). Outsiders do not have access to internal information and it is considered as substantial problem. Lajili and Zeghal (2005) state that promoting transparency and improving the quality of RRMID may lead to a lower level of information asymmetry. Such information is valuable to investors, creditors, analysts and other stakeholders as well.

It is expedient to analyze RRMID's evaluation methods, which are mostly examined in scientific literature and applied in practice. On the whole, information disclosure including RRMID is usually measured by analyzing annual reports of the companies. Annual reports are considered as the most accurate and reliable source of information about companies' financial situation and perspectives for the future. Moreover, annual reports are a tool to communicate with investors, to impress them and gain their trust. At the same time, companies can disclose not only mandatory but also voluntary information, which shows that companies are not hiding anything and are willing to cooperate.

Social science researchers who explore information disclosure methods refer to a wide range of different quantitative and qualitative methods. Quantitative methods are usually used for the analysis of numerical values. Often they cover financial categories such as assets or revenues. The assessment opportunities and choice of quantitative methods are wide. On the other hand, qualitative methods seek to evaluate the content and the composition of disclosed information, volume and clarity of information and different trends.

RRMID is specific in the sense that certain values or numbers are left aside and the presence and absence of textual risk information is analyzed. The main difficulty of this approach is how to properly measure the disclosed information (Healy and Palepu, 2001). In fact, in the literature there is no uniform standard way to measure the level of RRMID. Information disclosure is abstract by its nature. It does not contain typical characteristics by which it would be possible to determine its intensity and quality. However, authors 
usually use qualitative methods which allow systematizing and codifying different textual, visual and other information which is then examined by mathematical and statistical methods. Figure 1 illustrates the most commonly used qualitative methods used to analyze information disclosure.

\section{Figure 1 | Qualitative information disclosure evaluation methods}

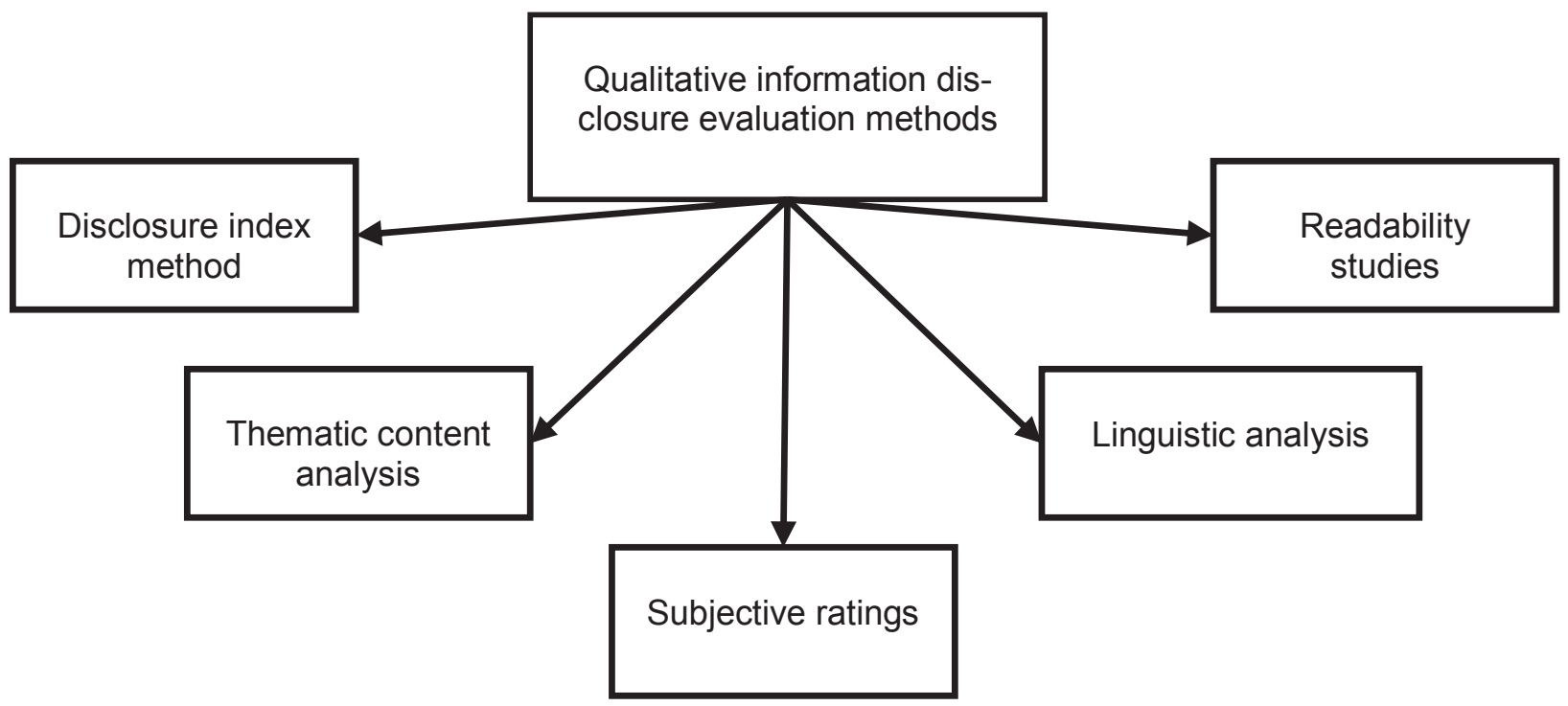

Source: modified according to V. Beattie et al. (2004)

\section{Methods}

Evaluation of the hypotheses that were developed in the introduction can be performed only after the overall RRMID evaluation is conducted. Assessment of risk and risk management information disclosure of listed Nasdaq OMX Baltic and Brussels Euronext companies follows the research process which includes three main stages (Table 2):

Table 2 | RRMID research stages and methods

\begin{tabular}{|l|l|l|}
\hline $\begin{array}{l}\text { Research } \\
\text { stages }\end{array}$ & \multicolumn{1}{|c|}{ Stages' goals } & \multicolumn{1}{c|}{ Research methods } \\
\hline Stage $\mathbf{1}$ & $\begin{array}{l}\text { To assess differences in RRMID characteristics } \\
\text { of companies listed in Nasdaq OMX Baltic and } \\
\text { Euronext Brussels. }\end{array}$ & $\begin{array}{l}\text { Content analysis } \\
\text { Coding process }\end{array}$ \\
\hline Stage $\mathbf{2}$ & $\begin{array}{l}\text { To analyze factors influencing RRMID of } \\
\text { companies listed in Nasdaq OMX Baltic and } \\
\text { Euronext Brussels. }\end{array}$ & $\begin{array}{l}\text { Data collection, Systemization and } \\
\text { visual presentation of data }\end{array}$ \\
\hline Stage $\mathbf{3}$ & $\begin{array}{l}\text { To test the relationships between RRMIDI } \\
\text { and factors influencing it. }\end{array}$ & $\begin{array}{l}\text { Correlation analysis } \\
\text { Regression analysis }\end{array}$ \\
\hline
\end{tabular}

Source: authors

1 Risk and risk management disclosure indicator 
The advantages and popularity among scholars led to the choosing of content analysis methods for RRMID in listed Nasdaq OMX Baltic and Euronext companies. Content analysis includes six main aspects: coding document, coding unit, coding rules, coding scheme, coding mode, and reliability and validity evidence (Rajab and HandleySchachler, 2009). In this research, the coding documents are companies' annual reports of year 2013, and the coding unit is a sentence.

In order to increase the credibility of content analysis and to minimize the differences between distinct coders, it is necessary to formulate clear and precise coding rules. In this research, coding rules are modified and adopted using several scholars' studies (Abraham and Cox, 2007; Linsley and Shrives, 2006, Vandemaele et al., 2009). Below the most important coding rules are listed:

1. A broad definition of risk is adopted (Linsley and Shrives, 2006) which includes an opportunity, threat, harm or exposure that may impact company in the future or have already impacted in the past. This also means that the word "risk" does not necessarily have to be mentioned in the sentence;

2. RRMID cannot be implicit. RRMID must be concrete and explicitly stated;

3. Sentences cannot be counted more than once, unless there is more than one possible classification;

4. RRMIDs references that are not clearly stated are not counted.

Coding scheme is the most important element in content analysis. It is a very complicated procedure, but at the same time it provides a detailed checklist for hypotheses' testing and helps one to not ignore relevant items. Scholars use different approaches to formulate coding schemes. Nevertheless, several categories dominate in a majority of studies. Summarized coding scheme based on P. Linsley and P. Shrives (2006) and V. Beattie et al. (2004) findings is presented in Figure 2.

All risk related disclosures are coded according to 6 elements: risk type, submission of information, nature of information, time orientation, type of information and type of disclosure. Each of the elements has sub-elements which increase the precision of categorization.

Coding mode prescribes whether the research is conducted using automated or manual approach. In this paper, the manual approach is chosen. Using a manual coding approach, the meanings of sentences are judged better (Deumes, 2008). Also, the entire annual report has to be read as it is done by external information users (Abraham et al., 2007). This increases the reliability of assessment (Beattie et al., 2004). Therefore, the coding mode used in this research is manual.

The research sample includes companies listed in Nasdaq OMX Baltic and Euronext Brussels stock exchanges. Nasdaq OMX Baltic stock exchange comprises of three countries: Estonia, Latvia and Lithuania. Nevertheless, it is still a developing and a quite small stock exchange as compared to Euronext Brussels stock exchange. Therefore, it is expected to obtain different results between the two markets.

Several criteria were set for the companies to fit into the sample: companies have to operate in non-financial industries; companies' annual reports have to be written in English; companies' financial statements have to be prepared in accordance with IFRS; 
companies' annual reports have to be easily available on their websites or on the stock exchange where the companies operate.

Euronext Brussels is twice as large in the number of listed companies. However, there are more financial companies and more companies haven't provided their annual reports to information users. Consequently, the overall data sample consists of 110 annual reports, 47 of Nasdaq OMX Baltic and 63 of Euronext Brussels.

To test the hypotheses, it is substantial to define the measures. Table 3 summarizes the measurements for all independent variables.

Figure 2 | RRMID disclosure coding scheme

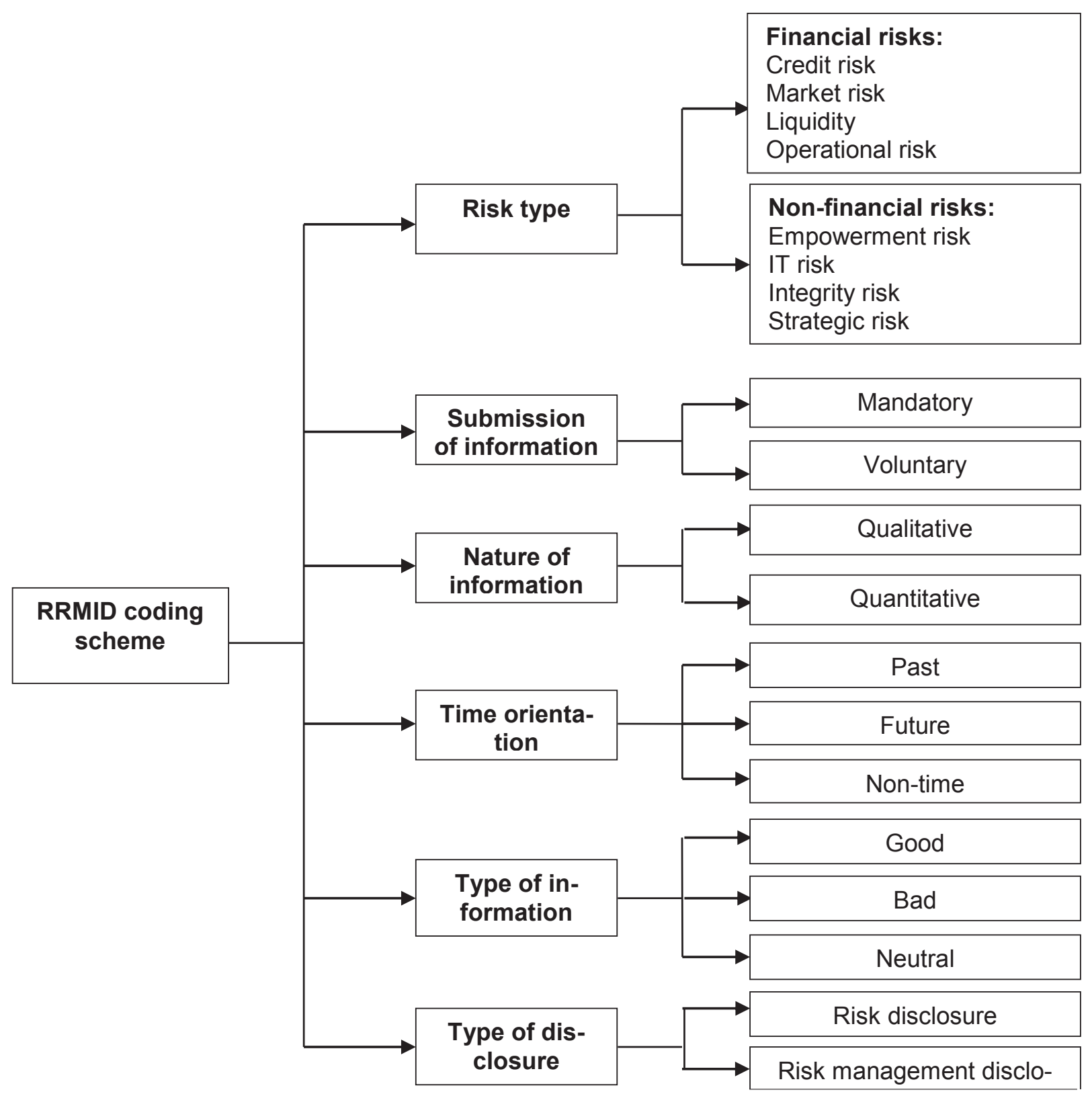

Source: adjusted according to P. Linsley and P. Shrives (2006) and V. Beattie et al. (2004)

Before the analysis of RRMID indicators and factors which possibly influence them, it is important to verify whether the relationships between these variables actually exist. For this reason, Spearman's correlation coefficient was estimated. 
Table 3 | Measurements of factors influencing RRMID

\begin{tabular}{|c|c|c|}
\hline \multicolumn{2}{|c|}{ Independent variable } & Measurement \\
\hline \multicolumn{3}{|c|}{ Company's specific characteristics } \\
\hline Company size & $\begin{array}{l}\text { Total asset } \\
\text { Number of employees } \\
\text { Total revenues }\end{array}$ & $\begin{array}{l}\text { Current assets + Non-current assets } \\
\text { Total number of workers } \\
\text { Total sales }\end{array}$ \\
\hline Industry & Industrial or service & Dummy variable \\
\hline Performance & Profitability & $\begin{array}{l}\text { ROE } \\
\text { ROA }\end{array}$ \\
\hline Liquidity & Current ratio & Current assets/Current liabilities \\
\hline Beta & Beta coefficient & $\operatorname{Cov}\left(r_{m}, r_{c}\right) / \operatorname{Var}\left(r_{m}\right)$ \\
\hline External auditor & "Big 4" or not & Dummy variable \\
\hline Listing duration & Time & $\begin{array}{l}\text { Number of years listed in stock } \\
\text { exchange }\end{array}$ \\
\hline \multicolumn{3}{|c|}{ Corporate governance characteristics } \\
\hline Ownership & Concentration of ownership & $\begin{array}{l}\text { Sum of shareholders having at least } 5 \% \\
\text { of total number of shares }\end{array}$ \\
\hline Board size & & Number of directors in the board \\
\hline Non-executives & & $\begin{array}{l}\text { Number of non-executives } \\
\text { in the board }\end{array}$ \\
\hline CEO duality & CEO $=$ Chairman or not & Dummy variable \\
\hline Internal audit & Presence of internal audit & Dummy variable \\
\hline Audit committee & Presence of audit committee & Dummy variable \\
\hline
\end{tabular}

Source: authors

Table 4 | Correlation coefficient interpretation

\begin{tabular}{|c|l|}
\hline Condition & \multicolumn{1}{|c|}{ Interpretation } \\
\hline$|\mathrm{r}|<0.3$ & Very weak correlation \\
\hline $0.3 \leq|\mathrm{r}|<0.5$ & Weak correlation \\
\hline $0.5 \leq|\mathrm{r}|<0.7$ & Moderate correlation \\
\hline $0.7 \leq|\mathrm{r}|<0.9$ & Strong correlation \\
\hline $0.9 \leq|\mathrm{r}|<1$ & Very strong correlation \\
\hline
\end{tabular}

Source: authors 
Later on 4 different regression models were conducted to check various factors' impact on RRMID. First, all factors were included in the regression model to see which have the highest impact on RRMIDI. Subsequently, regression models were conducted according to companies' specific characteristics and corporate governance characteristics. Finally, the last regression models were conducted according to results obtained in the correlation analysis. To make the models more accurate, the outliers were eliminated.

The first regression models with all factors involved were not suitable in both stock exchanges. Even though the determinations coefficients were quite high, 0.393 (Euronext Brussels) and 0.547 (Nasdaq OMX Baltic) but it is natural because of considerably large number of factors.

The most important are $p$-values, which show that neither of the first two models are significant. The same results were obtained in the second and third models, using specific companies' characteristics and corporate governance characteristics. The determination coefficient is partly normal, but $p$-values exceed 0.005 and factors were considered as not significant in these models.

The fourth model required better evaluation, because correlation analysis detected a weak or moderate relationship between several factors and RRMIDI. In the fourth model, factors for regression analysis in both stock exchanges were not the same. A size (total asset), external auditor, board size and non-executives are used for the Euronext Brussels market, while size (total revenues), external auditor and audit committee are taken for Nasdaq OMX Baltic market. Determination coefficients were appropriate $\left(\mathrm{R}^{2}>0.02\right)$ but still, they were quite low: 0.025 for Euronext Brussels companies and 0.342 for Nasdaq OMX Baltic companies. The most important thing is that $\mathrm{p}$-values for all factors were not significant. Nevertheless, the overall $p$-values in both cases were less than 0.001 . This implied that at least one variable was significant in the model and the model itself has to be improved. Hence, factors were eliminated one by one, according to their significance. Below an example of a regression model of Nasdaq OMX Baltic companies with factors having correlation relationship is provided:

Table 5 | Regression model summaryb

\begin{tabular}{|l|c|c|c|c|c|}
\hline \multicolumn{2}{|c|}{ Model } & R & R Square & Adjusted R Square & $\begin{array}{c}\text { Std. Error of the } \\
\text { Estimate }\end{array}$ \\
\hline dimension0 & 1 & $0.585^{\mathrm{a}}$ & 0.342 & 0.297 & 28.079 \\
\hline
\end{tabular}

a. Predictors: (Constant), Audit_committee, Size, External_auditor

b. Dependent Variable: RDI

Based on the above-mentioned research stages, in the first part of the research, detailed analysis of differences in RRMID characteristics of companies listed in Nasdaq OMX Baltic and Euronext Brussels is performed. The results showed that RRMIDI varies among stock exchanges. Companies listed in Euronext Brussels stock exchange on average disclose $34.57 \%$ more risk-related information than companies listed on Nasdaq OMX Baltic. The range between the lowest (9) and highest (264) disclosure is 255 sentences. On average companies disclose 103 risk-related sentences per company. 


\begin{tabular}{|l|l|r|r|r|r|r|}
\hline \multicolumn{2}{|c|}{ Model } & $\begin{array}{c}\text { Sum of } \\
\text { Squares }\end{array}$ & df & Mean Square & F & Sig. \\
\hline \multirow{3}{*}{1} & Regression & 17660.586 & 3 & 5886.862 & 7.466 & $<0.001^{\mathrm{a}}$ \\
\cline { 2 - 8 } & Residual & 33904.223 & 43 & 788.470 & & \\
\cline { 2 - 8 } & Total & 51564.809 & 46 & & & \\
\hline
\end{tabular}

a. Predictors: (Constant), Audit_committee, Size, External_auditor

b. Dependent Variable: RDI

\begin{tabular}{|l|c|c|c|c|c|c|c|}
\hline & & & & \multicolumn{2}{|c|}{$\begin{array}{c}\text { 95\% Confidence } \\
\text { Interval for B }\end{array}$} & \multicolumn{2}{|c|}{$\begin{array}{c}\text { Collinearity } \\
\text { Statistics }\end{array}$} \\
\cline { 5 - 8 } Model & B & t & Sig. & $\begin{array}{c}\text { Lower } \\
\text { Bound }\end{array}$ & $\begin{array}{c}\text { Upper } \\
\text { Bound }\end{array}$ & Tolerance & VIF \\
\hline Intercept & -79.349 & -1.391 & 0.171 & -194.360 & 35.662 & & \\
\hline Size & 8.242 & 2.011 & 0.051 & -0.024 & 16.508 & 0.828 & 1.207 \\
\hline External_auditor & 18.835 & 1.515 & 0.137 & -6.237 & 43.908 & 0.701 & 1.426 \\
\hline Audit__ & 28.567 & 2.266 & 0.029 & 3.142 & 53.992 & 0.833 & 1.201 \\
\hline
\end{tabular}

The obtained results also revealed that companies disclose more mandatory infor-mation than voluntary. This is valid for both stock exchanges. In total, $68 \%$ of coded risk-related information was mandatory (under IFRS 7) and 32\% voluntary. According to the risks types, market risk and credit risk composes a majority of RRMIDI in Nasdaq OMX Baltic, $33 \%$ and $28 \%$ respectively, while market risk (31\%) and operational risk (18\%) in Euronext Brussels. Further, as it was expected, companies disclose more qualitative than quantitative risk-related information. The overall distribution is $71 \%$ to $29 \%$, respectively. However, in the Nasdaq OMX Baltic stock exchange the difference is smaller, $58 \%$ to $42 \%$. The analysis also showed that companies provide much more information about risks than about risks' management. The total difference is $80 \%$ to $20 \%$, respectively. Moreover, the majority of disclosures are related with historical, backward-looking or present information (87\%) and only small part of the disclosed information is related with expectations and forwardlooking information (11\%). Finally, mostly risk-related information is neutral (72\%). Normally, there are general statements about risks or risk management disclosure disclosed. However, $14 \%$ of RRMIDI is considered as positive and showing an opportunity for a company. The rest, $14 \%$ indicates a negative event creating a negative effect for the company.

RRMIDI was also examined according to the type of industry. Overall, 9 industries were identified. However, huge differences between companies operating in different industries were not found. On average, telecommunication companies disclose the biggest amount of risk-related information - 134 sentences, utilities companies disclose least risk-related information - 93 sentences. 
In the second part of the research, an analysis of factors influencing RRMIDI was conducted. All factors are separated into companies' specific characteristics and corporate governance characteristics. The obtained results revealed that companies listed in the Euronext Brussels stock exchange are much larger in terms of total assets, number of employees and total revenues. The performance ratios (ROE, ROA) of both stock exchanges' companies are similar and normally fall into the interval from $0 \%$ to $10 \%$. However, there are less negatively operating companies in Nasdaq OMX Baltic stock exchange. There was also found that exact percentage $(81 \%)$ of Nasdaq OMX Baltic and Euronext Brussels companies are audited by one of the 'big 4' audit companies. Duration of being listed on stock exchange is longer of Euronext Brussels companies. Another important finding is that ownership concentration of Nasdaq OMX Baltic companies is much higher comparing to Euronext Brussels companies and in all cases exceeds $60 \%$. Finally, the results of CEO duality and the existence of internal audit and audit committee are similar. This indicates that RRMIDI and various factors might have inter-relationships, which were tested in part 3 of the research.

Correlation and regression analysis were performed in the third part of the research, to estimate existing relationships, their strength and directions between RRMIDI and various factors. The correlation analysis detected only a few weak relationships between several factors and RRMIDI. Weak correlation was determined between companies' size, external auditor, board size, number of non-executives and RRMIDI in Euronext Brussels stock exchange. Also weak correlation was determined between companies' size, external auditor, audit committee and RRMIDI in Nasdaq OMX Baltic. This signifies that different factors in different stock exchanges may influence RRMIDI.

In the regression analysis, 4 different models were examined: 1) including all factors, 2) including company-specific characteristics, 3) including corporate governance characteristics, 4) including factors having a weak or moderate relationship with RRMIDI determined by the correlation analysis. The adjusted regression models are provided in Table 8 .

\section{Table 8 | Results of the adjusted regression analysis}

\begin{tabular}{|l|l|c|c|c|}
\hline Stock exchange & \multicolumn{1}{|c|}{ Factors } & $\begin{array}{l}\text { Determination } \\
\text { coefficient - R }\end{array}$ & $p$-values & Regression equation \\
\hline Euronext Brussels & I) Size (total asset) & 0.227 & $<0.001$ & $\mathrm{RDI}=-72.346+12.197^{*} \mathrm{I}$ \\
\hline Nasdaq OMX Baltic & $\begin{array}{l}\text { I) Size (total revenues) } \\
\text { II) Audit committee }\end{array}$ & 0.307 & $\begin{array}{l}0.004 \\
0.004\end{array}$ & $\begin{array}{l}\mathrm{RDI}=-106.654+10.743^{*} \\
+36.152 * \text { II }\end{array}$ \\
\hline
\end{tabular}

Source: authors

The regression analysis affirmed that only companies' size is statistically significant in Euronext Brussels and only companies' size and audit committee is significant in Nasdaq OMX Baltic. Consequently, a majority of the factors are defined as insignificant and direct relationships were not found.

After the presentation of summarized research results, the verifications of raised hypotheses and their sub-hypotheses are presented further. As it is seen from Table 9, five out of six sub-hypotheses of the first hypothesis are supported. 
Table 9 | Results of hypothesis H1: sub-hypotheses 1-6 testing

\begin{tabular}{|c|c|c|c|c|c|}
\hline $\begin{array}{c}\text { Sub- } \\
\text { hypothesis }\end{array}$ & Stock exchange & Condition & $\begin{array}{c}\text { Difference } \\
\%\end{array}$ & Criteria & $\begin{array}{l}\text { Sub- } \\
\text { hypotheses } \\
\text { verification }\end{array}$ \\
\hline \multirow{3}{*}{$H_{1(1)}:$} & Nasdaq OMX Baltic & $3443>273$ & $85 \%$ & \multirow{3}{*}{$\geq 20 \%$} & \multirow{3}{*}{ Supported } \\
\hline & Euronext Brussels & $6001>1612$ & $58 \%$ & & \\
\hline & Total & $9444>1885$ & $67 \%$ & & \\
\hline \multirow{3}{*}{$H_{1(2)}:$} & Nasdaq OMX Baltic & $2138>1578$ & $15 \%$ & \multirow{3}{*}{$\geq 20 \%$} & \multirow{3}{*}{ Supported } \\
\hline & Euronext Brussels & $5889>1724$ & $55 \%$ & & \\
\hline & Total & $8027>3302$ & $42 \%$ & & \\
\hline \multirow{3}{*}{$H_{1(3)}:$} & Nasdaq OMX Baltic & $3577>129$ & $93 \%$ & \multirow{3}{*}{$\geq 20 \%$} & \multirow{3}{*}{ Supported } \\
\hline & Euronext Brussels & $6312>1088$ & $71 \%$ & & \\
\hline & Total & $9889>1217$ & $78 \%$ & & \\
\hline \multirow{3}{*}{$H_{1(4)}:$} & Nasdaq OMX Baltic & $542<3174$ & $-71 \%$ & \multirow{3}{*}{$\geq 20 \%$} & \multirow{3}{*}{ Rejected } \\
\hline & Euronext Brussels & $1071<6542$ & $-72 \%$ & & \\
\hline & Total & $1613<9716$ & $-72 \%$ & & \\
\hline \multirow{3}{*}{$H_{1(5)}:$} & Nasdaq OMX Baltic & $3165>551$ & $70 \%$ & \multirow{3}{*}{$\geq 20 \%$} & \multirow{3}{*}{ Supported } \\
\hline & Euronext Brussels & $5876>1737$ & $54 \%$ & & \\
\hline & Total & $9041>2288$ & $60 \%$ & & \\
\hline \multirow{3}{*}{$H_{1(6)}{ }^{:}$} & Nasdaq OMX Baltic & $3083>633$ & $66 \%$ & \multirow{3}{*}{$\geq 20 \%$} & \multirow{3}{*}{ Supported } \\
\hline & Euronext Brussels & $4637>2976$ & $22 \%$ & & \\
\hline & Total & $7720>3609$ & $36 \%$ & & \\
\hline
\end{tabular}

Source: authors

Since 5 out of 6 sub-hypotheses were supported, the hypothesis H1 is also supported and it is proven that RRMID is different in specific disclosure characteristics.

The second hypothesis consists of two parts: companies' specific characteristics (a) and corporate governance characteristics (b). Testing of Sub-hypotheses' results of the second hypothesis are summarized in Tables10, 11 and 12.

From Table 10, it is seen that only one sub-hypothesis is supported. Sub-hypothesis $\mathrm{H} 2 \mathrm{a}(2)$ is also rejected (Table 11). Companies operating in the same industry rarely provide close to the average amount of risk related information. Table 12 summarizes the second part of hypothesis H2. Sub-hypotheses H2b(1), H2b(2), H2b(3), H2b(4) and $\mathrm{H} 2 \mathrm{~b}(5)$ are rejected. This indicates that ownership concentration, board size, number of non-executives, CEO duality and internal control are not influential factors in terms of RRMID. 
Table 10 | Results of hypothesis H2: sub-hypotheses a(1) and a(3-6) testing

\begin{tabular}{|c|c|c|c|c|}
\hline $\begin{array}{c}\text { Sub- } \\
\text { hypothesis }\end{array}$ & Stock exchange & $\mathbf{R}$ & $P$-values & $\begin{array}{l}\text { Sub-hypotheses } \\
\text { verification }\end{array}$ \\
\hline \multirow{2}{*}{$H_{2 a(1)^{\circ}}$} & Nasdaq OMX Baltic & $\begin{array}{l}0.33^{*}>0 \\
0.33^{*}>0 \\
0.41^{* *}>0\end{array}$ & Significant & \multirow{2}{*}{ Supported } \\
\hline & Euronext Brussels & $\begin{aligned} 0.52^{* *} & >0 \\
0.46^{* *} & >0 \\
0.5^{* *} & >0\end{aligned}$ & Significant & \\
\hline \multirow{2}{*}{$H_{2 a(3)^{\circ}}$} & Nasdaq OMX Baltic & $\begin{array}{l}0.09>0 \\
0.02>0\end{array}$ & Not significant & \multirow{2}{*}{ Rejected } \\
\hline & Euronext Brussels & $\begin{array}{l}-0.08<0 \\
-0.08<0\end{array}$ & Not significant & \\
\hline \multirow{2}{*}{$H_{2 a(4)^{\circ}}$} & Nasdaq OMX Baltic & $-0.029<0$ & Not significant & \multirow{2}{*}{ Rejected } \\
\hline & Euronext Brussels & $-0.13<0$ & Not significant & \\
\hline \multirow{2}{*}{$H_{2 a(5)^{\circ}}$} & Nasdaq OMX Baltic & $0.04>0$ & Not significant & \multirow{2}{*}{ Rejected } \\
\hline & Euronext Brussels & $0.08>0$ & Not significant & \\
\hline \multirow{2}{*}{$H_{2 a(6)^{\circ}}$} & Nasdaq OMX Baltic & $0.44^{* *}>0$ & Not significant & \multirow{2}{*}{ Rejected } \\
\hline & Euronext Brussels & $0.30^{*}>0$ & Not significant & \\
\hline \multirow{2}{*}{$H_{2 a(7)^{\circ}}$} & Nasdaq OMX Baltic & $0.01>0$ & Not significant & \multirow{2}{*}{ Rejected } \\
\hline & Euronext Brussels & $0.1>0$ & Not significant & \\
\hline
\end{tabular}

Source: authors

Nevertheless, sub-hypothesis $\mathrm{H} 2 \mathrm{~b}(6)$ is partially accepted. Since 11 out of 13 sub-hypotheses were rejected, hypothesis $\mathrm{H} 2$ is also rejected. Companies' specific characteristics and corporate governance characteristics do not influence RRMID. 
Table 11 | Results of hypothesis H2: sub-hypothesis a(2) verification testing

\begin{tabular}{|c|c|c|c|c|c|c|}
\hline $\begin{array}{l}\text { Sub- } \\
\text { hypo- } \\
\text { thesis }\end{array}$ & Industry & $\begin{array}{l}\text { Number of } \\
\text { companies }\end{array}$ & $\begin{array}{l}\text { Number of } \\
\text { companies } \\
\text { exceeding } \\
\text { the criteria }\end{array}$ & $\begin{array}{c}\text { Difference } \\
\%\end{array}$ & Criteria & $\begin{array}{c}\text { Hypo- } \\
\text { theses } \\
\text { verification }\end{array}$ \\
\hline \multirow{9}{*}{$H_{2 a(2)^{\circ}}$} & Basic Materials & 9 & 7 & $78 \%$ & $> \pm 20 \%$ & \multirow{9}{*}{ Rejected } \\
\hline & Consumer Services & 13 & 11 & $85 \%$ & $> \pm 20 \%$ & \\
\hline & Consumer Goods & 25 & 17 & $68 \%$ & $> \pm 20 \%$ & \\
\hline & HealthCare & 12 & 8 & $67 \%$ & $> \pm 20 \%$ & \\
\hline & Industrials & 28 & 20 & $71 \%$ & $> \pm 20 \%$ & \\
\hline & Oil \& Gas & 2 & 2 & $100 \%$ & $> \pm 20 \%$ & \\
\hline & Technology & 9 & 8 & $89 \%$ & $> \pm 20 \%$ & \\
\hline & Telecommunication & 3 & 2 & $67 \%$ & $> \pm 20 \%$ & \\
\hline & Utilities & 9 & 6 & $67 \%$ & $> \pm 20 \%$ & \\
\hline
\end{tabular}

Source: authors

Table 12 | Results of hypothesis $\mathrm{H}_{2}$ : sub-hypothesis $b(1-6)$ testing

\begin{tabular}{|c|c|c|c|c|}
\hline Sub-hypothesis & Stock exchange & $\mathbf{R}$ & $P$ - values & $\begin{array}{l}\text { Sub-hypotheses } \\
\text { verification }\end{array}$ \\
\hline \multirow{2}{*}{$H_{2 b(1)}:$} & Nasdaq OMX Baltic & $-0.05<0$ & Not significant & \multirow{2}{*}{ Rejected } \\
\hline & Euronext Brussels & $-0.23<0$ & Not significant & \\
\hline \multirow{2}{*}{$H_{2 b(2)^{\prime}}$} & Nasdaq OMX Baltic & $-0.01<0$ & Not significant & \multirow{2}{*}{ Rejected } \\
\hline & Euronext Brussels & $0.28^{* *}>0$ & Not significant & \\
\hline \multirow{2}{*}{$H_{2 b(3)^{\circ}}:$} & Nasdaq OMX Baltic & $0.06>0$ & Not significant & \multirow{2}{*}{ Rejected } \\
\hline & Euronext Brussels & $0.32^{*}>0$ & Not significant & \\
\hline \multirow{2}{*}{$H_{2 b(4)}:$} & Nasdaq OMX Baltic & $-0.19<0$ & Not significant & \multirow{2}{*}{ Rejected } \\
\hline & Euronext Brussels & $0.16>0$ & Not significant & \\
\hline \multirow{2}{*}{$H_{2 b(5)}:$} & Nasdaq OMX Baltic & $0.09>0$ & Not significant & \multirow{2}{*}{ Rejected } \\
\hline & Euronext Brussels & $0.19>0$ & Not significant & \\
\hline \multirow{2}{*}{$H_{2 b(6)}:$} & Nasdaq OMX Baltic & $0.44^{* *}>0$ & Significant & \multirow{2}{*}{ Partially supported } \\
\hline & Euronext Brussels & $-0.11<0$ & Not significant & \\
\hline
\end{tabular}

Source: authors

Finally, the third hypothesis H3 is supported (Table 13). The research results show that the average RRMIDI is different between stock exchanges. 
Table 13 | Results of hypothesis H3: testing

\begin{tabular}{|l|l|c|c|c|}
\hline Hypothesis & Stock exchange & Difference & Criteria & $\begin{array}{c}\text { Hypotheses } \\
\text { verification }\end{array}$ \\
\hline H3: & $\begin{array}{l}\text { Euronext Brussels - } \\
\text { Nasdaq OMX Baltic }\end{array}$ & $35 \%$ & $\geq \pm 20 \%$ & Supported \\
\hline
\end{tabular}

To conclude, Table 14 summarizes all RRMID differences among companies listed in Nasdaq OMX Baltic and Euronext Brussels. There are significant differences of total RRMID. There were found 3716 risk related sentences in Nasdaq OMX Baltic companies' annual reports and 7613 risk-related sentences in Euronext Brussels companies annual reports. On average, companies listed in Nasdaq OMX Baltic and Euronext Brussels disclosed 79,1 and 120,8 sentences, respectively. Knowing that the lengths of sentences may vary significantly, the difference of 40 sentences is material.

Table 14 | Summarized results of differences in RRMID

\begin{tabular}{|c|c|c|c|c|c|}
\hline & & Nasda & OMX Baltic & Euron & t Brussels \\
\hline Total RRMIDI (senten & & & 716 & & 613 \\
\hline Average RRMIDI (sen & ences) & & 79.1 & & 20.8 \\
\hline & & Mean & \% of RRMIDI & Mean & $\%$ of RRMIDI \\
\hline Risk type & $\begin{array}{l}\text { Credit risk } \\
\text { Market risk } \\
\text { Liquidity risk } \\
\text { Operational risk } \\
\text { Empowerment risk } \\
\text { IT risk } \\
\text { Integrity risk } \\
\text { Strategic risk }\end{array}$ & $\begin{array}{r}21.7 \\
26.4 \\
17.4 \\
7.6 \\
0.8 \\
0.4 \\
0.3 \\
4.2\end{array}$ & $\begin{array}{r}27.6 \% \\
33.4 \% \\
22.0 \% \\
9.7 \% \\
1.1 \% \\
0.5 \% \\
0.4 \% \\
5.4 \%\end{array}$ & $\begin{array}{r}17.9 \\
37.8 \\
17.7 \\
21.6 \\
5.0 \\
4.3 \\
3.6 \\
12.6\end{array}$ & $\begin{array}{r}14.9 \% \\
31.3 \% \\
14.7 \% \\
17.9 \% \\
4.1 \% \\
3.6 \% \\
3.0 \% \\
10.5 \%\end{array}$ \\
\hline $\begin{array}{l}\text { Submission of } \\
\text { information }\end{array}$ & $\begin{array}{l}\text { Mandatory } \\
\text { Voluntary }\end{array}$ & $\begin{array}{l}65.6 \\
13.5\end{array}$ & $\begin{array}{l}83.0 \% \\
17.0 \%\end{array}$ & $\begin{array}{l}73.6 \\
47.2\end{array}$ & $\begin{array}{l}60.9 \% \\
39.1 \%\end{array}$ \\
\hline $\begin{array}{l}\text { Nature of } \\
\text { information }\end{array}$ & $\begin{array}{l}\text { Qualitative } \\
\text { Quantitative }\end{array}$ & $\begin{array}{l}45.5 \\
33.6\end{array}$ & $\begin{array}{l}57.5 \% \\
42.5 \%\end{array}$ & $\begin{array}{l}93.5 \\
27.4\end{array}$ & $\begin{array}{l}77.4 \% \\
22.6 \%\end{array}$ \\
\hline Time orientation & $\begin{array}{l}\text { Past or present } \\
\text { Future } \\
\text { Non-time }\end{array}$ & $\begin{array}{r}76.1 \\
2.7 \\
0.2\end{array}$ & $\begin{array}{r}96.3 \% \\
3.4 \% \\
0.3 \%\end{array}$ & $\begin{array}{r}100.1 \\
17.3 \\
3.4\end{array}$ & $\begin{array}{r}82.9 \% \\
14.3 \% \\
2.8 \%\end{array}$ \\
\hline Type of information & $\begin{array}{l}\text { Good } \\
\text { Bad } \\
\text { Neutral }\end{array}$ & $\begin{array}{r}11.5 \\
6.8 \\
60.7\end{array}$ & $\begin{array}{r}14.6 \% \\
8.6 \% \\
76.8 \%\end{array}$ & $\begin{array}{r}17 \\
19.2 \\
84.7\end{array}$ & $\begin{array}{l}14.1 \% \\
15.8 \% \\
70.1 \%\end{array}$ \\
\hline Type of disclosure & $\begin{array}{l}\text { Risk disclosure } \\
\text { Risk management } \\
\text { disclosure }\end{array}$ & $\begin{array}{l}67.3 \\
11.7\end{array}$ & $\begin{array}{l}85.2 \% \\
14.8 \%\end{array}$ & $\begin{array}{l}93.3 \\
27.6\end{array}$ & $\begin{array}{l}77.2 \% \\
22.8 \%\end{array}$ \\
\hline Factors influencing $\mathrm{F}$ & MID & $\begin{array}{l}\text { Compan } \\
\text { Presence } \\
\text { committ }\end{array}$ & $\begin{array}{l}\text { size; } \\
\text { f audit }\end{array}$ & Compani & size \\
\hline
\end{tabular}

Source: authors 
Even though the disclosure characteristics of companies listed in Nasdaq OMX Baltic and Euronext Brussels is different, the same trend is seen. Companies operating in both markets disclose more mandatory information, qualitative in nature and past or present oriented. Also, companies disclose more about risks itself and the disclosures are usually neutral. However, the factors influencing RRMID are different. Only companies' size is a significant factor in the Euronext Brussels stock exchange. Companies' size and the presence of audit committee are significant factors in the Nasdaq OMX Baltic stock exchange.

\section{Conclusions}

The research is unique, because comparative studies of differences in RRMID among emerging and developed markets were not found. To achieve the research objective, 3 main hypotheses were raised, which include 19 sub-hypothesis. To accept or reject hypotheses, criteria were set with the findings justified by the literature review.

The empirical research includes 3 stages. In stage 1, differences in RRMID characteristics of companies listed in Nasdaq OMX Baltic and Euronext Brussels are analyzed. For this reason, content analysis was conducted. In stage 2, the analysis of factors influencing RRMID is performed. In stage 3, the relationship between RRMIDI and various factors are tested. To test the relationship, correlation and regression analysis were conducted.

Companies listed in Nasdaq OMX Baltic and Euronext Brussels disclose different amount of risk-related information. On average, companies listed in Nasdaq OMX Baltic disclose 79 sentences per company, while companies listed in Euronext Brussels 120 sentences per company.

Companies disclose more mandatory than voluntary information. This gap is more significant in the Nasdaq OMX Baltic stock exchange. By nature RRMID is more qualitative than quantitative in both markets, and companies in both markets provide more information about risks than about risk management. The majority of risk-related information is backward or present looking. However, Euronext Brussels companies disclose more forward-looking information. The type of information is neutral in both markets (around 70\%).

Factor analysis showed that companies listed in Euronext Brussels are significantly larger compared to Nasdaq OMX Baltic companies, and they are listed in the stock exchange for a longer time period. Also, the ownership concentrations of Nasdaq OMX Baltic companies are significantly higher, board sizes are smaller and they have fewer non-executives.

Correlation analysis showed that weak and moderate relationship exist between RRMIDI and companies' size, external auditor, board size and non-executives in the Euronext Brussels stock exchange. In Nasdaq OMX Baltic weak correlation was determined between RRMIDI and companies' size, external auditor and audit committee.

Regression analysis approved the significance of companies' size in Euronext Brussels and companies' size and audit committee in Nasdaq OMX Baltic. However, it is important to note that this analysis does not reveal the causation, but rather analyzes the association between variables.

The research results in some cases confirm foreign scholars' findings, but there are also some contradictions. The first hypothesis stating that RRMID is different in specific 
disclosure characteristics is accepted. The second hypothesis is rejected, meaning that companies' specific characteristics and companies' corporate governance characteristics do not significantly influence RRMID. Third hypothesis is accepted, and differences of level in RRMID among the companies listed in Nasdaq OMX Baltic and Euronext Brussels have been found.

The research method is a limitation of this thesis. Therefore, it is suggested to apply different research methods and compare the obtained results. The disclosure index method could be one of the possibilities. Also, to improve the credibility of research results, it is recommended to apply Scoot's pi test. For this reason, computer software is needed. Moreover, several coders should use the same approach and compare whether the coding rules and coding scheme is identically understood.

The research sample is considerably small. More emerging and developed markets could be involved to improve the quality of research results. At the same time, coding documents could consist not only of annual reports, but also other companies-related documents, such as corporate governance reports or material events announcements.

It is also recommended to broaden the research extent performing inquiries of investors, questioning whether they actually read risk and risk management information and what exactly they are looking for in such disclosures.

For companies, it is recommended to provide more risk and risk management information. This could reduce the costs of capital and attract more investors. However, the information has to be specific for the company, more forward looking and with potential meaning.

For regulators, it is recommended to stimulate companies for better risk-related information disclosure, especially about non-financial risks. This is particularly important for companies listed in Nasdaq OMX Baltic stock exchange.

Regulators' influence on risk and risk management disclosure could be more significant and the supervision of compliance with the requirements might be stricter.

\section{References}

Abraham, S., \& Cox, P. (2007). Analysing the determinants of narrative risk information in UK FTSE 100 annual reports. The British Accounting Review, 39(3), 227-248.

Abraham, S., Solomon, A., \& Stevenson, J. (2007). A ranking of risk disclosure in UK annual reports. Working paper. Edinburgh, UK: Napier University.

Barako, D.G., Hancock, P., \& Izan, H.Y. (2006). Factors influencing voluntary corporate disclosures by Kenyan companies. Corporate Governance: An International Review, 14(2).

Beattie, V., McInnes, B., \& Fearnley, S. (2004). A methodology for analyzing and evaluating narratives in annual reports: a comprehensive descriptive profile and metrics for disclosure quality attributes. Accounting Forum, 28(3), 205-236.

Cabedo, J., \& Tirado, J. (2004). The disclosure of risk in financial statements. Accounting Forum, 28(2), 181-200.

Deumes, R. (2008). Corporate risk reporting a content analysis of narrative risk disclosures in prospectuses. Journal of business communication, 45(2), 120-157.

Dobler, M. (2008). Incentives for risk reporting - A discretionary disclosure and cheap talk approach. The International Journal of Accounting, 42(2), 184-206.

Domínguez, L. R., \& Gámez, L. C. N. (2014). Corporate reporting on risks: Evidence from Spanish companies. Spanish Accounting Review, 17(2), 116-129 
Healy, P., \& Palepu, K. (2001). Information asymmetry, corporate disclosure, and the capital markets: A review of the empirical disclosure literature. Journal of Accounting and Economics, 31(1), 405-440.

ICAEW (2002). No surprises: the case for better risk reporting. Balance Sheet. The Institute of Chartered Accountants in England and Wales, 10(4).

Lajili, K., \& Zeghal, D. (2005). A content analysis of risk management disclosures in Canadian annual reports. Canadian Journal of Administrative Sciences, 22(2), 125-142.

Linsley, P., \& Shrives, P. (2006). Risk reporting: A study of risk disclosures in the annual reports of UK companies. The British Accounting Review, 38(4), 387-404.

Mackevičius, J. (2006). Imonių veiklos rizikų rūšys ir jų vertinimo būtinumas. Vilnius: Vilniaus universitetas.

Rajab, B., \& Handley-Schachler, M. (2009). Corporate risk disclosure by UK firms: trends and determinants. World Review of Entrepreneurship Management and Sustainable Development, 5(3), 224-243.

Vandemaele, S., Vergauwen, P., \& Michels, A. (2009). Management Risk Reporting Practices and their Determinants: A Study of Belgian Listed Firms. Working Paper, Hasselt University.

\section{Authors}

\section{Dalia Kolmatsui, PhD}

Associate Professor

Finance Department, Faculty of Economics and Management

Vytautas Magnus University

S.Daukanto 28, Kaunas, Lithuania

Dalia.Kolmatsui@vdu.It

\section{Renata Legenzova, PhD}

Associate Professor, Head of Department

Finance Department, Faculty of Economics and Management

Vytautas Magnus University

S.Daukanto g. 28, LT- 44246 Kaunas, Lithuania

Renata.Legenzova@vdu.It

\section{Mantas Seilius}

Master of Economics

Finance Department, Faculty of Economics and Management

Vytautas Magnus University

S.Daukanto 28, Kaunas, Lithuania

mantas.seilius@fc.vdu.It 